Tena Hoško*

Dora Zgrabljić Rotar**
Original scientific paper

UDK 341.96:347.518

347.518(4-67EU: 497.5)

DOI: http://doi.org/10.25234/pv/8276

Paper received: 1 March 2019

Paper accepted: 22 March 2019

\title{
APPLICATION OF THE 1971 HAGUE CONVENTION ON TRAFFIC ACCIDENTS IN CROATIA
}

Summary: $\quad$ The paper examines the Croatian case law where the 1971 Hague Convention on Traffic Accidents has been applied. Some relatively recent cases show that the Croatian Supreme Court applied the general conflict-of-laws rule on determining the law applicable to the non-contractual obligation of the Croatian Private International Law Act where it should have applied the 1971 Hague Convention. The most recent decisions from 2009 and 2013 indicate that, even after more than 40 years of application, the problem of basic understanding of the sources of private international law still exists. On the other hand, there are a number of decisions where the 1971 Hague Convention has been applied and in which some issues repeatedly arise. Most of them relate either to the application of Article 8 of the Hague Convention dealing with the scope of the applicable law or application of Article 4 of the Convention providing for exceptions to the main rule of the lex loci delicti commissi found in Article 3 of the Convention. The problematic decisions fall into the category of decisions applying the exceptions under Article 4 of the Convention. The decisions in which the court has applied Article 8 of the Convention show that Croatian courts have recognized the idea behind the provision (as explained in the Essén explanatory report), which was to give as wide a scope as possible to the applicable law.

Keywords: $\quad$ conflict-of-laws rules for traffic accidents, Hague Convention on Traffic Accidents of 1971, lex loci delicti commissi, scope of the applicable law

\footnotetext{
Tena Hoško, PhD, Assistant Professor, Faculty of Law, University in Zagreb, Republike Hrvatske Square 14, 10000 Zagreb, Republic of Croatia. E-mail address: tena.hosko@pravo.hr. ORCID: https://orcid.org/0000-0002-6745-0351.

** Dora Zgrabljić Rotar, PhD, Assistant Professor, Faculty of Law, University in Zagreb, Republike Hrvatske Square 14, 10000 Zagreb, Republic of Croatia. E-mail address: dora.zgrabljic.rotar@pravo.hr. ORCID: https://orcid.org/0000-0002-6558-4532.
} 


\section{CONFLICT-OF-LAWS RULES ON CROSS-BORDER TRAFFIC ACCIDENTS IN FORCE IN CROATIA}

The former Socialist Federal Republic of Yugoslavia (hereinafter: SFRY) was among the first signatories of the 1971 Hague Convention on the Law Applicable to Traffic Accidents (hereinafter: 1971 Hague Convention, Convention). SFRY became a party to the Convention on 16 December 1975. After the Croatian declaration of independence, the Convention was applicable in Croatia based on the Constitutional Decision on Independence and Sovereignty. ${ }^{1}$ Under that decision, all the treaties in force in former Yugoslavia, which were not contrary to Croatian public policy, were applicable in Croatia from the date of its independence, 8 October 1991.

According to Article 141 of the Croatian Constitution, international treaties are a part of internal law in Croatia and they have precedence over national laws. There has been, however, a number of cases where the courts have applied the rules of national law where they should have applied the applicable international treaties. ${ }^{2}$ We consider some of these cases in this paper.

The 1971 Hague Convention had precedence in application over the provisions of the Croatian Private International Law Act applicable to non-contractual obligations. ${ }^{3}$ The application of the Convention is universal - the Convention applies even when the applicable law is not the law of a contracting state, and it does not require reciprocity. ${ }^{4}$ Thus, Croatian courts have been applying the 1971 Hague Convention for more than 40 years, namely since 1975, in all disputes over traffic accidents with an international element. While court practice is consistent in the application of the provisions of the 1971 Hague Convention in Croatia, unfortunately it has not always been consistent with the interpretation and case law of the Convention in other contracting parties to the Convention. In part III.2.3 of this paper, we analyse the cases in which Croatian courts have repeatedly interpreted Article 4 of the Convention against the practice of national courts of other contracting parties to the Convention.

Private international law has been codified in Croatia since 1982 when the Private International Law $\mathrm{Act}^{5}$ was originally enacted as a federal statute of the former Socialist Federative Republic of Yugoslavia. ${ }^{6}$ The original text of the law was taken over as the law of Croatia in

$1 \quad$ Official Gazette No. 31/1991.

2 High Commercial Court, decision no. Pž-1010/93 of 18 May 1993; High Commercial Court, decision no. Pž-335/92 of 24 March 1992 (applying Article 28 of the Conflict of Laws Act and not the 1971 Hague Convention on the Law Applicable to Traffic Accidents); Supreme Court of Croatia, decision no. Gzz 28/92 of 5 May 1993 (applying Article 31 of the Conflict of Laws Act and not the 1961 Hague Convention on the Conflicts of Laws Relating to the Form of Testamentary Dispositions). (Sajko, K.; Sikirić, H.; Bouček, V.; Babić, D.; Tepeš, N., Izvori hrvatskog i europskog međunarodnog privatnog prava, Informator, Zagreb, 2001, pp. 148-149).

3 For the most part, the Croatian codification of the private international law of torts was reduced to a single provision contained in Article 28 of the Private International Law Act. This provision applied to nearly all the types of tort liability (e.g. personal injury cases, violation of privacy and personality rights, intellectual property infringements, damage arising from the violation of competition laws, etc.). Specific statutory rules on the applicable law are provided only for maritime and airline traffic accidents, which appeared in the Maritime Code and the Act on Obligations and Property Rights in Air Traffic. According to Article 28(1) of the 1982 Private International Law Act, the law governing tortious liability is the law of the place where the act was performed or the law of the place where the consequences occurred, whichever is more favourable for the victim.

4 Article 11 of the Convention.

5 Zakon o rješavanju sukoba zakona s propisima drugih zemalja u određenim odnosima, Official Gazette No. 53/1991.

6 Official Gazette SFRY No. 43/1982 and 72/1982. 
1991, when the country declared independence. ${ }^{7}$ The Private International Law Act has not been affected by the major legislative reforms carried out in the 1990s, when Croatia underwent transition from a socialist economy to a market-based economy.

Croatia joined the European Union (hereinafter: EU) on 1 July 2013. Since that date, the Rome II Regulation ${ }^{8}$ has had precedence over national conflict-of-laws rules that coincide with its scope of application. For the purpose of the transitory provisions of the regulation, the date of Croatia's accession is treated as the day when the regulation entered into force. ${ }^{9}$ Thus, in line with the principle of non-retroactivity, ${ }^{10}$ the Rome II Regulation applies to events occurring after 1 July 2013 (Article 31 Rome II Regulation). ${ }^{11}$ The law applicable to events that occurred prior to that date is determined according to the rules of the Croatian Private International Law Act of 1982 and other rules of internal Croatian private international law. ${ }^{12}$

The Rome II Regulation applies, in situations involving a conflict of laws, to non-contractual obligations in civil and commercial matters and does not apply, in particular, to revenue, customs or administrative matters, or additionally to state liability for acts and omissions in the exercise of state authority (acta iure imperii) (Article 1). This provision of the Rome II Regulation is followed by a list of explicitly excluded non-contractual obligations.

With the need to reform private international law, the bill for a new Private International Law Act (hereinafter: PILA) was passed by the Croatian Parliament on 4 October 2017 and came into effect on 29 January 2019. ${ }^{13}$ Until that date, the 1982 Private International Law Act was in effect in Croatia. ${ }^{14}$ The new Croatian PILA is a comprehensive codification of private international law and it establishes conflict-of-laws rules as well as rules on jurisdiction and recognition and enforcement of foreign decisions on status, family law matters, property law relationships, and other substantive legal relationships involving a foreign element. The 2017 PILA aligns the rules with the current trends in private international law, but, more impor-

7 Babić, D., Private International Law in Josipović, T. (ed.), Introduction to the Law of Croatia, Wolters Kluwer, Alphen aan den Rijn 2014, p. 439. The only major change since 1982 was that the rules on recognition and enforcement of arbitral awards were abolished and replaced by the Arbitration Act of 2001, Official Gazette No. 88/2001, Article 50.

8 Regulation (EC) No 864/2007 of the European Parliament and of the Council of 11 July 2007 on the law applicable to noncontractual obligations (Rome II), OJ L 199, 31 July 2007, pp. 40-49.

9 Article 2 of the Act Concerning the Conditions of Accession of the Republic of Croatia to the Treaty on European Union, the Treaty on the Functioning of the European Union and the Treaty Establishing the European Atomic Energy Community, Official Gazette, International Treaties, OJ L 300, 9 November 2013, pp. 22-35.

10 Babić, D., Opće uređenje starnačkog izbora mjerodavnog prava prema Uredbi (EZ) 593/2008 o pravu mjerodavnom za ugovorne obveze (Rim I), Zagrebačka pravna revija, Vol. 5, No. 3, 2016, p. 273.

11 The same principle applies to the timely application of other European regulations in Croatia, e.g. the Brussels I Regulation applies to legal proceedings instituted and to documents formally drawn up or registered as authentic instruments after 1 July 2013 (Article 66 Council Regulation (EC) No 44/2001 of 22 December 2000 on jurisdiction and the recognition and enforcement of judgments in civil and commercial matters, OJ L 351, 20 December 2012, pp. 1-32). Babić, D., Vremenske granice primjene uredaba 44/2001 i 1215/2012 u Hrvatskoj in J. Garašić (ed.), Europsko građansko procesno pravo, Narodne novine, Zagreb, 2013, p. 140. Babić, op. cit. note 10, p. 273.

13 Zakon o međunarodnom privatnom pravu, Official Gazette No. 101/2017.

14 The original name has been changed from the Act Concerning the Resolution of Conflicts of Laws with the Provisions of Other Countries in Certain Matters (Zakon o rješavanju sukoba zakona s propisima drugih zemalja u odredenim odnosima) to the Private International Law Act (Zakon o medunarodnom privatnom pravu). The old name of the statute is not only lacking in elegance, but is also misleading - the Act does not govern only conflict of laws, but also other aspects of private international law in the wider sense, such as international jurisdiction and the recognition and enforcement of foreign judgments. 
tantly, it provides rules consistent with the principles and ideas of European private international law and the unification process of European private international law.

With the aim to simplify the ratione materiae application of the diverse legal sources of private international law that are in effect in Croatia, the 2017 Croatian PILA has an explicit provision which directs the courts to apply the Rome II Regulation to determine the applicable law in disputes over non-contractual obligations that fall within the scope of application of the Regulation. ${ }^{15}$

Moreover, according to the 2017 Croatian Private International Law Act, the law applicable to non-contractual obligations that fall outside the scope of the application of the Rome II Regulation, and are not governed by another provision of national or international law in force in Croatia, is also determined according to the provisions of the Rome II Regulation. ${ }^{16}$ PILA also explicitly provides that when determining the law applicable to traffic accidents with a foreign element, the courts shall apply the 1971 Hague Convention. ${ }^{17}$

This is in accordance with Article 28(1) of the Rome II Regulation which provides that the international convention to which one or more Member States are parties and which lays down conflict-of-laws rules relating to non-contractual obligations will have precedence over the Rome II Regulation.

Thus, in Croatia, the law applicable to non-contractual obligations will be determined in accordance with the rules of the Rome II Regulation in all cases, except for those covered by the conventions that are in force in Croatia - namely the 1971 Hague Convention, the Hague Convention of 2 October 1973 on the Law Applicable to Products Liability, ${ }^{18}$ and the Vienna Convention on Civil Liability for Nuclear Damage of 21 May 1963. ${ }^{19}$

The subject matter of this paper is an in depth analysis of Croatian courts' case law where the 1971 Hague Convention was applied and exploration of its rules that present problems in practice with the purpose to contribute to a more appropriate application of the Convention in Croatia.

\section{THE PROBLEM OF THE DUAL REGIME FOR CROSS-BORDER TRAFFIC ACCIDENTS IN THE EU}

Croatia is therefore one of the EU Member States in which the courts have to apply the 1971 Hague Convention rules to determine the law applicable to cross-border traffic accidents.

15 Article 26(1) of the 2017 PILA.

16 Article 26(2) of the 2017 PILA.

17 Article 27 of the Rome II Regulation.

18 Official Gazette SFRY, International Treaties Nos. 26/1976, 8/1977. Pursuant to the notification of succession, which was submitted by Croatia on 22 January 1994, Croatia has been a party to the Convention since 8 October 1991, Official Gazette, International Treaties No. 4/1994.

19 Official Gazette SFRY, International Treaties Nos. 5/1977. Pursuant to the notification of succession, which was submitted by Croatia on 22 January 1994, Croatia has been a party to the Convention since 8 October 1991, Official Gazette, International Treaties No. 12/1993. 
However, not all EU Member States are also contracting states to the Convention, which has led to the much-debated issue of the existing two different regimes for determining the law applicable to traffic accidents in the EU. Approximately half of the EU Member States have ratified the Convention: Austria, Belgium, Croatia, the Czech Republic, France, Latvia, Lithuania, Luxemburg, the Netherlands, Poland, Slovakia, Slovenia and Spain. ${ }^{20}$ In all other EU Member States, the courts apply the rules of the Rome II Regulation to determine the law applicable to cross-border traffic accidents. These countries are: Bulgaria, Cyprus, Estonia, Finland, Germany, Greece, Hungary, Ireland, Italy, Malta, Portugal, Romania, Sweden and the United Kingdom. Finally, in Denmark the courts apply neither of the two sources but the autonomous national private international law. ${ }^{21}$

Thus, depending on which Member States' courts decide on the law applicable to cross-border accidents, the applicable law will generally be determined either in accordance with the rules of the Rome II Regulation or in accordance with the rules of the 1971 Hague Convention. Since there are some dissimilarities between the two legal sources, the outcome might be the application of different substantive law. This opens the path to forum shopping and is, as pointed out by many scholars, contrary to the principal aim of the Rome II Regulation - uniformity of the conflict-of-laws rules for non-contractual obligations. ${ }^{22}$ According to the Calliess Commentary, "this shows that the European Union and its institutions preferred to fulfil international law obligations by the Member States and thus protect international relations rather than achieve an isolated regional unification" ${ }^{23}$

The conflict-of-laws rules in the Convention and those in the Rome II Regulation could, because of their similarities, potentially lead to the same law as applicable to a traffic accident. The general rule in the Rome II Regulation is that the law applicable to non-contractual obligations is the law of the country where the damage occurred, i.e. lex loci damni. The general rule in the 1971 Hague Convention is that the law applicable to traffic accidents is the law of the State where the accident occurred, i.e. lex loci delicti commissi. In reality, this will in the vast majority of cases lead to the same result, since the place of delictum and the place of damnum, except in a very limited number of cases, coincide in traffic accidents. ${ }^{24}$ The differences between the two regimes derive from the exceptions to the main rules that are based on completely different approaches. The Rome II Regulation bases its exception on the common habitual residence of the parties, while the Convention bases its exceptions on the domicile of the vehicle.

An interesting point of debate among scholars, and the apparent diversity in the application of the 1971 Hague Convention by the courts of its respective contracting states, derives from the fact that the Convention is silent on the issue of the choice of law by the parties.

20 Information on the states that are Contracting Parties to the Convention available at: https:/www.hcch.net/en/instruments/ conventions/status-table/?cid=81. Accessed 19 February 2019.

21 According to recital 40 of the Preamble to the Rome II Regulation "in accordance with Articles 1 and 2 of the Protocol on the position of Denmark, annexed to the Treaty on European Union and to the Treaty establishing the European Community, Denmark does not take part in the adoption of this Regulation, and is not bound by it or subject to its application".

22 Calliess, G. P., Rome Regulations - Commentary, Wolters Kluwer, 2nd. ed., 2015, p. 827; Nagy, C. I., The Rome II Regulation and Traffic Accidents: Uniform Conflict Rules with Some Room for Forum Shopping - How So? Journal of Private International Law, Vol. 6, No. 1, 2010, p. 93; Sibinga, A. C., Crossing Borders: What Happens When Rome Meets the Hague? Journal of Personal Injury Law, Vol. 1, 2014, p. 13.

23 Calliess, op. cit. note 22, p. 824. 
Still, there are a number of Dutch cases where the courts have upheld the parties' choice of law under the 1971 Hague Convention, allowing it even before the accident occurred. ${ }^{25}$ Looking from the Croatian perspective, it is to be noted that in none of the cases analysed has the court considered a choice of law under the 1971 Hague Convention. It is rather unlikely that the Croatian courts would allow such a choice given that this is not expressly regulated in the Convention. On the other hand, the parties' freedom to choose the applicable law is allowed in the Rome II Regulation, but is limited to the time after the event giving rise to the damage incurred. Even though party autonomy is not expressly envisaged by the Convention, allowing it would contribute to the uniform resolution of non-contractual disputes within the EU.

\section{CROATIAN CASE LAW REGARDING THE 1971 HAGUE CONVENTION}

The case law acquired consists of twenty-six decisions of Croatian courts that relate to the 1971 Hague Convention. They are mostly decisions by the Supreme Court of Croatia, a few decisions are issued by different county courts (Split, Varaždin, Vukovar and Zagreb) while one decision was rendered by the High Commercial Court and one by a municipal court (Zagreb). The Croatian legal system does not accept the doctrine of precedent; however, lower courts are influenced by the decisions of the appellate courts, as well as the decisions of the Supreme Court and the Constitutional Court.

This paper examines the issues in the Convention that are present in the acquired case law. The first part of this section deals with the issue of the mandatory application of the Convention (III.1). Even though it might seem evident that the application of the Convention is mandatory, there are some decisions where the courts have erred on the issue of the mere application of the Convention. Thereafter, a few issues of the scope of application of the applicable law are discussed in the second part of the section - the kinds and extent of damages (III.2.1), the assignability and inheritability of the right to damages (III.2.2), the issue of the law applicable to determine the persons who have suffered damage and who may claim damages in their own right (III.2.3), and, lastly, the insurance coverage limit (III.2.4).

\subsection{MANDATORY APPLICATION OF THE CONVENTION}

In the Republic of Croatia, conflict-of-laws rules are mandatory in their legal nature. ${ }^{26}$ This means they are to be applied ex officio and without being invoked by either of the parties. The parties at the same time cannot renounce the application of conflict-of-laws rules. The lack of the proper application of the conflict-of-laws rules is thus a valid reason for appeal and

25 Sibinga, op. cit. note 22, p. 18.

26 Sikirić, H., Primjena kolizijskih pravila i stranog prava u sudskom postupku, Zbornik Pravnog fakulteta u Zagrebu, Vol. 56, No. 2-3, 2006, p. 672; Župan, M., Pravo najbliže veze u hrvatskom i europskom međunarodnom privatnom ugovornom pravu, Pravni fakultet u Rijeci, Rijeka, 2006, p. 199; Sajko, K., Međunarodno privatno pravo, Narodne novine, Zagreb, 2009 , p. 229. 
revision ${ }^{27}$ which has also been confirmed in cases involving traffic accidents with a foreign element. $^{28}$

Furthermore, international agreements have precedence over national law in the Croatian legal system. According to Article 141 of the Croatian Constitution, "international agreements which have been concluded and ratified in accordance with the Constitution and which have been published and have entered into force shall be a part of the internal legal order of the Republic of Croatia and shall have primacy over domestic law". ${ }^{29}$ In the context of the relationship between the 1971 Hague Convention and the Croatian 1982 PIL Act, it is clear the Convention as an international agreement had primacy over the PIL Act when it applied to traffic accidents with an international element. ${ }^{30}$ It is thus surprising to find decisions of Croatian courts which wholly disregard the Convention and rely solely on the PIL Act for the determination of the governing law for traffic accidents. ${ }^{31}$ Thankfully, most decisions do apply the Convention, as will be demonstrated below. Besides, one quite old decision of the Supreme Court of 1990 revokes the decisions of lower courts and remands the case for re-trial due to the non-application of the Convention. ${ }^{32}$

\subsection{SCOPE OF APPLICATION OF THE APPLICABLE LAW UNDER THE CONVENTION}

The scope of the application of the governing law determined by the Convention's conflict-of-laws rules is enshrined in its Article 8. Given that the provision states that the applicable law governs in particular the enumerated matters, the list is non-exhaustive ${ }^{33}$ and covers, amongst other things:

(1) the basis and extent of liability;

(2) the grounds for exemption from liability, any limitation of liability, and any division of liability;

(3) the existence and kinds of injury or damage which may have to be compensated;

(4) the kinds and extent of damages;

27 Dika, M.; Knežević, G.; Stojanović, S., Komentar Zakona o međunarodnom privatnom i procesnom pravu, Nomos, Beograd, 1991, p. 50; Sikirić, op. cit. note 26, p. 672.

28 Supreme Court, decision no. Rev-x 237/13-2 of 28 December 2013; Supreme Court, decision no. Rev-x 135/08-2 of 17 June 2009; Supreme Court, decision no. II Rev 19/1992-2 of 13 December 1994; High Commercial Court, decision no. Pž-335/92 of 24 March 1992. All decisions are published at www.iusinfo.hr.

29 Official Gazette, Nos. 56/1990, 135/1997, 113/2000, 28/2001, 76/2010.

30 Nowadays, the application of the Hague Convention of 1971 is required by the Rome II Regulation itself, as explained above.

31 Supreme Court, decision no. Rev-x 237/13-2 of 28 December 2013; Supreme Court, decision no. Rev-x 135/08-2 of 17 June 2009; Supreme Court, decision no. II Rev 19/1992-2 of 13 December 1994; Supreme Court, decision no. II Rev 22/1992-2 of 28 April 1992; High Commercial Court, decision no. Pž-335/92 of 24 March 1992. All decisions are published at www.iusinfo.hr.

32 Supreme Court, decision no. Rev 1513/1990-2 of 13 November 1990. Decision published on https://sudskapraksa.csp.vsrh.hr/ search.

33 Essén, E. W., Explanatory Report of the Convention on the law applicable to traffic accidents, 1970, p. 28. URL= https://assets.hcch. net/upload/expl19e.pdf. Accessed 23 February 2019. 
(5) the question whether a right to damages may be assigned or inherited;

(6) the persons who have suffered damage and who may claim damages in their own right;

(7) the liability of a principal for the acts of his agent or of a master for the acts of his servant;

(8) rules of prescription and limitation, including rules relating to the commencement of a period of prescription or limitation, and the interruption and suspension of this period.

Croatian case law has dealt with several matters, in particular Article 8, points 4, 5 and 6 of the 1971 Convention.

\subsubsection{THE KINDS AND EXTENT OF DAMAGES}

Croatian courts have had an opportunity to deal with the issue of the law applicable to the extent of damages that are to be compensated. There are two different groups of cases depending on the facts of the cases.

The first group of cases deals with the issue of the calculation of the amount of damages when moral damage is to be compensated. ${ }^{34}$ In these cases, foreign law was applicable as the lex causae. The question arose whether Croatian law as lex fori applies to the determination of the amount of damages. More precisely, the issue was whether so-called orientation criteria for the determination of the amount of moral damages that are issued by the Supreme Court of the Republic of Croatia are to be applied. In one of the cases, the party that claimed the application of those criteria based its reasoning on the fact that the moral damage was sustained in Croatia, which warrants the application of the Croatian orientation criteria. In all three cases, the Supreme Court determined that when the foreign law is applicable, the criteria established in that law - in case law or otherwise - are to be applied. It explained that the application of the lex fori would lead to "an unequal application of the same legal norm when foreign law is applied with respect to the determination of the amount of moral damages when that law is applied by Croatian courts" ${ }^{35}$ Such an interpretation of Croatian courts is in line with the wording and the aim of the 1971 Hague Convention as explained in its Explanatory Report. ${ }^{36}$ Essentially, if foreign law is applicable, it is to be applied in its entirety, including its criteria for the determination of the extent of damage.

The second group of cases deals with a different issue regarding the amount of compensation that was discussed before the second-instance courts. In those cases, Croatian law was the lex causae as the law of the state where the accident occurred in accordance with Article 3 of the Convention. The typical scenario was that the damage on the vehicle was repaired in a foreign country (Germany), primarily for the sake of convenience, due to the fact that the car owner was domiciled/resident there. Since prices in Germany were then, and still are, higher than in Croatia, the liable party claimed that such, more expensive, repairs should not be com-

34 Supreme Court, decision no. Rev 744/11-3 of 13 September 2016; Supreme Court, decision no. Rev x 470/2014-2 of 1 April 2015; Supreme Court, decision no. Rev 1000/2009-2 of 28 April 2010. All decisions are published on www.iusinfo.hr.

35 “(...) došlo bi do nejednake primjene iste pravne norme kod primjene stranog materijalnog prava u pogledu određivanja visine nematerijalne štete, a koje materijalno pravo primjenjuju hrvatski sudovi”, Supreme Court, decision no. Rev 1000/2009-2 of 28 April 2010. 
pensated, i.e. that the repairs should have been done in Croatia. Once again, the courts took a correct stance by concluding that the full price of the car repair done in Germany was to be compensated, ${ }^{37}$ including VAT. ${ }^{38}$ Such a stance is supported by the fact that Croatian law as the lex causae determines the extent of damages that is to be compensated and it provides for full compensation (natural restitution or restitution in integrum). ${ }^{39}$ This means that compensation is to be made in accordance with the principle of equivalence, i.e. the compensation must be equal to the damage incurred. ${ }^{40}$ The amount of damage, and then compensation, is the usual price which is calculated based on the market value. ${ }^{41}$ The courts specifically emphasised that the car owner lives in Germany and is thus authorised to repair the car there. The courts stated that the repair was "necessary and required", implying that there was no bad faith on the side of the victim - the car owner. In one of the cases, the Supreme Court further elaborated that the extent of expenses incurred in a foreign country depends on special circumstances and the higher amount of expenses is only to be covered if such circumstances exist. ${ }^{42}$

In that particular case the special circumstance was the foreign nationality of the victim who made the repairs. Once again, the courts decided in line with the Convention, considering that the lex causae, under the rule contained in Article 8(4) of the Convention, was applicable to determine the "amount of the redress due". ${ }^{43}$

\subsubsection{THE QUESTION WHETHER A RIGHT TO DAMAGES MAY BE ASSIGNED OR INHERITED}

Only one available case has dealt with the question of the inheritability of the right to damages. ${ }^{44}$ In that case, the victim of the car accident died, not in the accident itself, but afterwards, and the heirs instituted proceedings against the insurer of the person liable for the accident. The traffic accident occurred in Hungary and the Hungarian law was applicable according to Article 3 of the 1971 Hague Convention. The first-instance court viewed the issue of the inheritability of the claim as governed by the lex causae (although invoking the incor-

37 County Court in Varaždin, decision no. Gž-3190/15-2 of 28 September 2016; County Court in Varaždin, decision no. Gž 1519/15-3 of 13 January 2016 (decisions are published at www.iusinfo.hr); County Court in Split, decision no. Gžnš-193/2012 of 11 December 2013 (not published); County Court in Zagreb, decision no. Gžn-1945/10-2 of 8 March 2011 (not published).

38 Supreme Court, decision no. Rev 2480/10-2 of 14 January 2014; Supreme Court, decision no. Rev-x 280/11-2 of 11 December 2013. Decisions published at https://sudskapraksa.csp.vsrh.hr/search.

39 Articles 1085 and 1090 of the Croatian Obligations Act, Official Gazette Nos. 35/2005, 41/2008, 125/2011, 78/2015. Klarić, P.; Vedriš, M., Građansko pravo, Narodne novine, 2006., 10. ed., Zagreb, p. 633.

40 Vizner, B., Komentar Zakona o obveznim (obligacionim) odnosima, Zagreb, self-published, 1978-1979, p. 841; Perović, S.; Stojanović, D., Komentar Zakona o obligacionim odnosima, Knjiga prva, Kultuni centar, Pravni fakultet Kragujevac, Gornji Milanovac, Kragujevac, 1980, p. 566.

41 Article 1089/2 of the Croatian Obligations Act. Vizner, op. cit. note 40, p. 846; Perović, Stojanović, op. cit. note 40, p. 562; Blagojević, B. T.;. Krulj, V., Komentar Zakona o obligacionim odnosima, Savremena administracija, Belgrade, 1983, 2. ed., p. 703; Klarić, Vedriš, Essén, op. cit. note 39, p. 633.

42 Supreme Court, decision no. Rev 2395/10-2 of 28 December 2012. Decision published at https://sudskapraksa.csp.vsrh.hr/ search. This had already been established in earlier case law of the Supreme Court, decision no. Rev 417/93 of 22 December 1993. Cited in Ćesić, Z.; Gorenc, V.; Kačer, H.; Momčinović, H.; Pavić, D.; Perkušić, A.; Pešutić, A.; Slakoper, Z., Vidović, A.; Vukmir, B., Komentar Zakona o obveznim odnosima, RRiF-plus, Zagreb, 2005, p. 1693.

43 Essén, op. cit. note. 33, p. 30. 
rect provision of foreign law); however, the second-instance court decided that the lex fori was applicable. The Supreme Court, on the other hand, correctly decided that the application of the lex fori was contradictory to the Convention which in its Article 8(5) expressly states that the issue of the possibility of the assignment or inheritance of the right to damages is to be governed solely by the lex causae. In essence, according to that provision, the lex causae applies to the question whether the victim can assign its personal right to damages and whether such a right can be inherited. This is to be differentiated from the issue of the claims of heirs of the victim who died in the accident, which is covered by Article 8(6) of the Convention. ${ }^{45}$

When the issue of the inheritability of the damages claim was discussed at the Hague Conference, two opposite standpoints were expressed. First, that the issue of inheritability is to be governed by the general law governing succession (lex successionis) and, second, accepted in the text of the Convention, that the issue should be governed by the lex causae as determined by the Convention. ${ }^{46}$ The lex fori as the governing law, which was the stance taken by the Croatian county court, was not in the picture at all.

\subsubsection{PERSONS WHO HAVE SUFFERED DAMAGE AND WHO MAY CLAIM DAMAGES IN THEIR OWN RIGHT}

The most intriguing case law has developed with regard to the interpretation of Article 8(6) in connection with Article 4(1)(a) ( $2^{\text {nd }}$ indent) of the 1971 Hague Convention. Article 4(1)(a) ( $2^{\text {nd }}$ indent) of the 1971 Hague Convention provides for an exception to the general rule for the determination of the applicable law. It foresees that the law of registration of the vehicle (lex tabuli) is to be applied "towards a victim who is a passenger and whose habitual residence is in a State other than that where the accident occurred". The habitual residence is determined at the time when the accident occurs. ${ }^{47}$ The ratio behind the exception is that the law of registration is more relevant for the person who has no habitual residence in the country where the accident occurred as he or she will most often have habitual residence in the country of registration of the vehicle in the same way as the person responsible for the accident. ${ }^{48}$ If nothing else, that law is predictable and easily ascertainable. ${ }^{49}$ That law then determines, according to Article 8(6) of the Convention, "the persons who have suffered damage and who may claim damages in their own right".

The Supreme Court has had a few opportunities to interpret these two provisions from 2006 onwards. The case law in crux deals with the determination of the applicable law in the case where the lex tabuli is not equal to the lex loci delicti commissi, and the exception under Article 4 of the Convention could thus be applied. The facts were more or less the same in all cases. A car accident occurs in one country, country $\mathrm{X}$, and the car is registered in another country, country

\footnotetext{
45 Essén, op. cit. note 33, p. 30.

46 Ibid.

47 Essén, op. cit. note 33, p. 20.

48 Ibid.

49 Ibid
} 
Y. ${ }^{50}$ In some cases, two cars are involved and are both registered in the same country which would under Article 4(b) of the Convention lead to the application of the common lex tabuli. ${ }^{51}$ The accident has a fatality who was a passenger in one of the vehicles. It is not always clear where the victim had habitual residence. The determination of habitual residence is important in terms of the applicability of the exception contained in Article 4 of the Convention since it only applies to victims that had no habitual residence in the country where the accident occurred. In most cases, however, it is certain or reasonable to conclude that the habitual residence of the victim was not in the country where the accident occurred. In any case, the determination of habitual residence was not at the centre of judicial review in those cases anyway.

The plaintiffs in those cases were indirect victims, persons who were relatives of the deceased victim, either parents or children, who suffered moral damage precisely because of the death of their close relative. The question arose which law was applicable to the obligations arising out of the accident towards them. Or, in other words, does the exception under Article 4(1)(a) ( $2^{\text {nd }}$ indent) that determines the lex tabuli as applicable to liability towards a victim who is a passenger apply to liability towards indirect victims as well? In the view of the Croatian courts, the mentioned exception only applies to victims who are passengers, that is, the direct victim, and not the indirect victims that are plaintiffs in those cases. The outcome is that the applicable law was determined by virtue of the general rule enshrined in Article 3 of the Convention.

However, the Convention clearly envisages that the determination of the applicable law comes prior to determining who is a victim since the applicable law determines the persons who have suffered damage and who may claim damages in their own right according to Article 8(6) of the Convention. This means that the applicable law applies to direct and indirect victims all the same, or, better to say, that the lex causae determines whether indirect victims may claim damages. This is clear from the Explanatory Report of Essén that states that indirect victims who may have the right to moral damages "are totally assimilated with the direct victim for the purpose of determination of the applicable law (...) Their claims are therefore governed by the law which determines or would have determined questions of liability towards the direct victim". ${ }^{52}$ If the reasoning of the Croatian courts were followed, the solution may turn out to be quite impractical and illogical since the determination of the applicable law would depend on the survival of the direct victim. ${ }^{53}$ From all of the above, it is to be concluded that the stance taken by the Croatian courts was contrary to the systematic, teleological and historical interpretation of the Conven-

50 In some cases, the accident occurred in Croatia and the car was registered elsewhere (Supreme Court, decision no. Rev 452/20092 of 20 March 2012; Supreme Court, decision no. Rev 878/2008-2 of 18 February 2010 (the decisions are published at www. iusinfo.hr); Municipal Court in Zagreb, Pn 1088/09 of 23 December 2010 (cited in Tomljenović, V., Tumačenje kolizijskih pravila međunarodnih konvencija - primjer tumačenja kolizijskih odredbi Haaške konvencije o prometnim nezgodama in Sikirić, H.; Bouček, V.; Babić, D. A.; Petrak, M.; Gliha, I. (eds.), Liber amicorum Krešimir Sajko: zbornik radova u čast prof. em. Krešimiru Sajku, Zagreb, Pravni fakultet Sveučilišta u Zagrebu, 2012, p. 110) and in some it was vice versa (Supreme Court, decision no. Rev 744/11-3 of 13 September 2016; County Court in Vukovar, Gž 1710/2003 of 12 November 2003 (the decisions are published at www.iusinfo. hr).

51 Article 4/b of the Hague Convention of 1971: "Where two or more vehicles are involved in the accident, the provisions of a) are applicable only if all the vehicles are registered in the same State."

52 Essén, op. cit. note 33, p. 21.

53 Babić, D., The Hague Convention on Road Traffic Accidents in Croatian Courts: An Exercise of Strict Textualism in Vasiljević, M.; Kulms, R.; Josipović, T.; Stanivuković, M. (eds.), Private Law Reform in South East Europe, Liber amicorum Christa Jessel-Holst, Faculty of Law, University of Belgrade, Belgrade, 2010, pp. 463-464. 
tion..$^{54}$ The autonomous interpretation of the Convention is thereby endangered and leads to the non-uniformity of decisions in the national case law of the contracting states. ${ }^{55}$

Unfortunately, in the most recent judgments of the Supreme Court from 2016, the Court expressly stated that the mentioned case law had been established over many years in several judgments of the Court and should not be changed. ${ }^{56}$ It elaborates that "it is about the judicature in accordance with a stable, established (long-standing) and consistent case law of the revision court that - precisely because it is based on the correct interpretation of the above provisions, it would be constitutionally unacceptable (from the aspect of legal certainty and the rule of law and equality before the law) to change it". ${ }^{57}$

Our research came across only one judgment in which the lex tabuli was found to be the applicable law. ${ }^{58}$ In the case before the County Court in Varaždin, the question arose as to the law applicable to damage occurring to four plaintiffs due to the death of their relative ${ }^{59}$ who died in a car accident as a passenger. The accident took place in Slovenia between two cars with Croatian registration. The court of first instance applied Slovenian law by virtue of Article 3 of the 1971 Hague Convention. The County Court revoked the decision due to the incorrect application of substantive law. In the court's view, Croatian law was to be applied as the common lex tabuli according to Article 4 of the Convention. However, it seems that the court relied on Article 4(a) ( $1^{\text {st }}$ indent) of the 1971 Hague Convention. Under that provision, the lex tabuli applies to determine liability "towards the driver, owner or any other person having control of or an interest in the vehicle". The judgment implies that the court's understanding is that the provision applies to determine the liability of the driver (the defendant in that case was the driver's insurance company) and not towards the driver. ${ }^{60}$ Even though the court applied the wrong provision, the result was a more satisfactory one since it led to the application of the proper law.

\subsubsection{INSURANCE COVERAGE LIMIT}

When victims seek damages, it is usually that they seek it from the wrongdoer's insurance company. It is, of course, in their interest that the law that provides for the higher insurance limit applies. Wrongdoers and their insurers, on the other hand, prefer the application of the

54 Babić, op. cit. note 53, pp. 462-465.

55 See more in Tomljenović, op. cit. note 53, pp. 101-152.

56 The Supreme Court mentions its six previous judgments (Rev-x 802/13-2 of 26 March 2014; Rev 452/09-2 of 20 March 2012; Rev 1000/09-2 of 28 April 2010; Rev 878/08-2 of 18 February 2010; Rev 218/08-2 of 13 May 2009; Rev 1166/04-2 of 14 June 2006).

57 The Supreme Court in its decision no. Rev 744/11-3 of 13 September 2016: “(..) riječ je o suđenju u skladu s stabilnom, ustaljenom (dugogodišnjom) i dosljednom sudskom praksom revizijskog suda - koju bi upravo stoga što je takva i temeljena na pravilnom tumačenju navedenih odredaba bilo ustavnopravno neprihvatljivo (s aspekta pravne sigurnosti i vladavine prava te jednakosti svih pred zakonom) mijenjati."

58 County Court in Varaždin, decision no. Gž 1219/2006-02 of 15 May 2006 (the decision is published at https://sudskapraksa.csp. vsrh.hr/search).

59 Most probably the wife, one child, mother and brother of the deceased, although it is not completely clear from the facts of the case.

60 “(...) primjenjuje se unutarnje pravo države registracije, među ostalim, i na odgovornost vozača vozila koje je sudjelovalo u prometnoj nezgodi" [... the internal law of the state of registration governs, inter alia, liability of the driver of the vehicle that took part in the accident]. 
law that provides for lower insurance limits. In two cases before Croatian courts, the issue was which insurance coverage limit was to be applied. ${ }^{61}$ The law applicable to the traffic accidents was the Croatian law determined pursuant to Article 3 of the Convention, i.e. it was the lex loci delicti commissi. The cars whose insurers were sued were registered in a foreign country (Germany and the Netherlands) and in both cases the limit determined by the insurance contract was much higher than the domestic minimum. The courts took the stance that the limit determined by the foreign law applicable to the insurance contract was relevant, because the law determined by the Convention does not apply to the insurance limit. Even more, domestic laws do not limit the highest, only the lowest amount.

However, Article 8(4) of the Convention determines that the same law is applicable to the kinds and extent of damages. The extent of liability is to be interpreted in the manner that "if there is a maximum fixed by law, this is determined by the law deemed applicable to liability by virtue of the Convention". ${ }^{2}$ Similarly, "if the lex fori fixes a maximum of damages payable while the foreign law applicable to liability does not have such a limit, the judge ought to follow the foreign law" ${ }^{63}$ It is thus to be concluded that the maximum damage payable should be determined by the lex causae. In the same vein, Pappetas concludes that the law applicable to the payment of damages by the insurer under the Convention is either the lex loci delicti commissi or the lex tabuli. ${ }^{64}$

In any case, the Croatian courts came to a fair outcome since Croatian law as the lex causae did not foresee any maximum whatsoever. There was no obstacle to award damages that were higher than the minimum determined by the lex causae.

Today in the EU, not only are the Rome II Regulation and the 1971 Hague Convention concurrent with respect to determining the law applicable to traffic accidents, but the EU has also regulated the issue of the law applicable to car insurance in its Motor Insurance Directive (hereinafter: MID). ${ }^{65}$ Given that it is an EU instrument that ensures that all the Member States respect the minimum coverage, its rules cannot be undermined by the 1971 Hague Convention. ${ }^{66}$ It will thus regulate the law applicable to insurance coverage even in countries that are signatories to the 1971 Hague Convention. Conflict-of-laws rules are foreseen in Articles 3 and 14 of the Directive. Under Article 3(a) of the MID: "Each Member State shall take all appropriate measures to ensure that the contract of insurance also covers: a) according to the law in force in other Member States, any loss or injury which is caused in the territory of those states". Under Article 14(b) of the MID, the Member State shall take all appropriate steps to ensure that compulsory policies of motor insurance "b) guarantee, on the basis of [a] single

61 Supreme Court, decision no. Rev-x 496/15-2 of 28 July 2015 (the decision is published at https://sudskapraksa.csp.vsrh.hr/ search); Supreme Court, decision no. Rev 218/2008-02 of 13 May 2009 (the decision is published at www.iusinfo.hr).

62 Essén, op. cit. note supra n. 33, p. 28.

63 Essén, op. cit. note 33, p. 30.

64 Papettas J. on request by the European Parliament's Committee on Legal Affairs, Directorate General for Internal Policies, Policy Department C: Citizens' Rights and Constitutional Affairs, Legal Affairs, Choice of Law for Cross Border Road Traffic Accidents: Rome II, the Hague Convention and the Motor Insurance Directive, PE 462.492, 2012 p. 20. URL= http://www.europarl.europa.eu/ document/activities/cont/201212/20121219ATT 58306/20121219ATT58306EN.pdf. Accessed 13 February 2019.

65 Directive 2009/103/EC of the European Parliament and of the Council of 16 September 2009 relating to insurance against civil liability in respect of the use of motor vehicles, and the enforcement of the obligation to insure against such liability, OJ L 263, 7 October 2009, pp. 11-31. 
premium, in each Member State, the cover required by its law or the cover required by the law of the Member State where the vehicle is normally based when that cover is higher". Essentially, these rules lead to the application either of the law of the place where the accident occurred or the place of registration, depending which of the two provides for higher coverage. The applicable law can therefore, just as under the Convention, be either the lex loci delicti commissi or the lex tabuli. However, the Convention determines the applicable law based on the closest connection, whereas, under the MID rules, the law is determined based on the principle of favourability to the victim, i.e. favor laesi. ${ }^{67}$

\section{CONCLUSION}

Croatian courts have been applying the 1971 Hague Convention on the law applicable to cross-border traffic accidents for more than 40 years in all disputes over traffic accidents with an international element. Court practice has been consistent in the application of the provisions of the 1971 Hague Convention in Croatia, although unfortunately it has not always been consistent with the envisaged aims and interpretation of the Convention.

Even more problematic is the fact that some relatively recent cases show that the Croatian Supreme Court has applied the conflict-of-laws rule on determining the law applicable to the non-contractual obligation of the Croatian Private International Law Act where it should have applied the 1971 Hague Convention. The most recent decisions are from 2009 and 2013, so it is clear that there is still, even after more than 40 years of application, a problem in the basic understanding of the sources of private international law. What is remains to be researched is whether entrance into force of the Rome II Regulation in Croatia will lead to further ambiguity in understanding of the hierarchy of private international law sources. Hopefully, the new Private International Act of 2017 will facilitate an accurate application of different legal sources.

However, there is a significant number of cases where the courts applied the 1971 Hague Convention which we examined and categorised by issues in this paper.

We found several decisions by the Supreme Court and other appellate courts that deal with the issue of the quantification of damages, precisely with subparagraph 4 of Article 8 which provides that the applicable law will determine the kinds and extent of damages.

In two of those decisions by the Supreme Court - one from 2010 and the other from 2016 - in which the court decided on the issue of quantification of damages according to Article 8 of the 1971 Hague Convention, the Court took the stand that when deciding the amount of damages, Croatian courts should not apply the orientation criteria for determining damages provided by the Croatian Supreme Court, but the criteria and court practice of the state whose law is applicable, i.e. the lex causae.

A further four decisions of different county courts in Croatia dealt with a similar issue two of them were rendered by the county court in Varaždin (both in 2016), one was rendered by the county court in Split in 2013, and one by the county court in Zagreb in 2011. All of them 
basically deal with the same or a very similar factual situation - in all cases the traffic accident occurred in Croatia, and thus, according to the lex loci delicti commissi rule, Croatian law was applicable. In all cases, the cars were registered in a different country (in all cases Germany) and the owners of the vehicles and the victims had their habitual residence in Germany and in all cases the defendants claimed that since Croatian law was applicable the amount of the redress payable should be determined in accordance with the prices of car repair in Croatia. But the courts held that given that the Croatian law was applicable means that the Croatian Civil Obligations Act is applicable and since the Act has a full restitution provision the victims are entitled to cover costs in the way most suitable for them, which is in accordance with the prices in the country where they reside.

The last issue found regarding Article 8 was the issue of the inheritance of the claim. In a decision of the Supreme Court of Croatia rendered in 2015, the court remanded a lower court decision with an explanation that it is not the lex fori that governs the inheritance of the claim, but the lex causae (and in that particular case it was Hungarian law). This stance is in line with Article 8(5) of the Convention according to which the applicable law determines the question whether a right to damages may be assigned or inherited.

Probably the most problematic issue is that of the interpretation of Article 4 of the Convention. Namely, the Supreme Court of Croatia has taken the stance that in traffic accidents involving only one vehicle or two vehicles registered in the same country different from the one in which the damage occurred when the claim is submitted by the persons who are indirectly harmed by the accident, usually the relatives of the deceased victim, the applicable law is the law of the place where the accident occurred, whereas, at the same time under the same circumstance if the claim were submitted by the direct victims, the applicable law would be the law of the place of registration. This is in contrast to the decisions of courts in other countries that are members of the 1971 Hague Convention, as well as to its aims, and shows that the Supreme Court of Croatia prefers the rigid and literal application of the Convention to a meaningful and just outcome.

It is thus evident from the case law of the Croatian courts that there is room for improvement when it comes to application of different legal sources in the area of private international law. The authors are sure that the improvement would be achieved by resorting to the research of case law of other contracting states' courts and scholarly writings when applying the Convention.

\section{BIBLIOGRAPHY}

1. Babić, D., Opće uređenje stranačkog izbora mjerodavnog prava prema Uredbi (EZ) 593/2008 o pravu mjerodavnom za ugovorne obveze ("Rim I"), Zagrebačka pravna revija, vol. 5, br. 3, 2016, pp. 271-294.

2. Babić, D., Private International Law in Josipović, T. (ed.), Introduction to the Law of Croatia, Wolters Kluwer, Alphen aan den Rijn 2014, pp. 439-454.

3. Babić, D., The Hague Convention on road traffic accidents in Croatian courts: an exercise of strict textualism in Vasiljević, M.; Kulms, R.; Josipović, T.; Stanivuković, M. (eds.), Private law reform in South east Europe, Liber amicorum Christa Jessel-Holst, Faculty of Law, University of Belgrade, Belgrade, 2010, pp. 458-466. 
4. Babić, D., Vremenske granice primjene uredaba 44/2001 i 1215/2012 u Hrvatskoj in J. Garašić (ed.), Europsko građansko procesno pravo, Narodne novine, Zagreb, 2013, pp. 137-146.

5. Blagojević, B. T.;. Krulj, V., Komentar Zakona o obligacionim odnosima, Savremena administracija, Belgrade, 2. ed., 1983.

6. Callies, G. P., Rome Regulations - Commentary, Wolters Kluwer, 2. ed., 2015.

7. Ćesić, Z.; Gorenc, V.; Kačer, H.; Momčinović, H.; Pavić, D.; Perkušić, A.; Pešutić, A.; Slakoper, Z.; Vidović, A.; Vukmir, B., Komentar Zakona o obveznim odnosima, RRiF-plus, Zagreb, 2005.

8. Dika, M.; Knežević, G.; Stojanović, S., Komentar Zakona o međunarodnom privatnom i procesnom pravu, Nomos, Beograd, 1991.

9. Klarić, P.; Vedriš, M., Građansko pravo, Narodne novine, 2006, 10. ed., Zagreb

10. Nagy, C. I., The Rome II Regulation and the Traffic Accidents: Uniform Conflict Rules with Some Room for Forum Shopping - How so?, Journal of Private International Law, Vol. 6, No. 1, 2010 , pp. 93-108.

11. Perović, S.; Stojanović, D., Komentar Zakona o obligacionim odnosima, Knjiga prva, Kultuni centar, Pravni fakultet Kragujevac, Gornji Milanovac, Kragujevac, 1980.

12. Sajko, K., Međunarodno privatno pravo, Narodne novine, Zagreb, 2009.

13. Sajko, K.; Sikirić, H.; Bouček, V.; Babić, D.; Tepeš, N., Izvori hrvatskog i europskog međunarodnog privatnog prava, Informator, Zagreb, 2001.

14. Sibinga, A. C., Crossing Borders: What Happens When Rome Meets the Hague, Journal of Personal Injury Law, Vol. 1, 2014, pp. 13-19.

15. Sikirić, H., Primjena kolizijskih pravila i stranog prava u sudskom postupku, Zbornik Pravnog fakulteta u Zagrebu, Vol. 56, No. 2-3, 2006, pp. 671 - 686.

16. Tomljenović, V., Tumačenje kolizijskih pravila međunarodnih konvencija - primjer tumačenja kolizijskih odredbi Haaške konvencije o prometnim nezgodama in Sikirić, H.; Bouček, V.; Babić, D. A.; Petrak, M.; Gliha, I. (eds.), Liber amicorum Krešimir Sajko: zbornik radova u čast prof. em. Krešimiru Sajku, Zagreb, Pravni fakultet Sveučilišta u Zagrebu, 2012, pp. 101-151.

17. Vizner, B., Komentar Zakona o obveznim (obligacionim) odnosima, Zagreb, self-published, 1978-1979.

18. Župan, M., Pravo najbliže veze u hrvatskom i europskom međunarodnom privatnom ugovornom pravu, Pravni fakultet u Rijeci, Rijeka, 2006.

\section{LEGAL SOURCES}

1. Act Concerning the Conditions of Accession of the Republic of Croatia to the Treaty on European Union, the Treaty on the Functioning of the European Union and the Treaty Establishing the European Atomic Energy Community, Official Gazette, International Treaties, OJ L 300, 9 November 2013, pp. 22-35.

2. Act concerning the resolution of conflicts of laws with the provisions of other countries in certain matters (Zakon o rješavanju sukoba zakona s propisima drugih zemalja u određenim odnosima), Official Gazette SFRY No. 43/1982 and 72/1982, Official Gazette No. 53/1991.

3. Arbitration Act, Official Gazette No. 88/2001. 
4. Constitution of the Republic of Croatia (Ustav Republike Hrvatske) Official Gazette Nos. 56/1990, 135/1997, 113/2000, 28/2001, 76/2010.

5. Council Regulation (EC) No 44/2001 of 22 December 2000 on jurisdiction and the recognition and enforcement of judgments in civil and commercial matters, OJ L 351, 20 December 2012, pp. 1-32.

6. Directive 2009/103/EC of the European Parliament and of the Council of 16 September 2009 relating to insurance against civil liability in respect of the use of motor vehicles, and the enforcement of the obligation to insure against such liability, OJ L 263, 7 October 2009, pp. 11-31.

7. Hague Convention of 2 October 1973 on the Law Applicable to Products Liability, Official Gazette SFRY, International Treaties Nos. 26/1976, 8/1977, Official Gazette, International Treaties No. 4/1994.

8. Hague Convention on the Law Applicable to Traffic Accidents of 4 May 1971, Official Gazete No. 31/1991.

9. Obligations Act (Zakon o obveznim odnosima), Official Gazette Nos. 35/2005, 41/2008, 125/2011, $78 / 2015$.

10. Private international law act (Zakon o međunarodnom privatnom pravu), Official Gazette No. 101/2017.

11. Regulation (EC) No 864/2007 of the European Parliament and of the Council of 11 July 2007 on the law applicable to non-contractual obligations (Rome II), OJ L 199, 31 July 2007, pp. 40-49.

12. Vienna Convention on Civil Liability for Nuclear Damage of 21 May 1963, Official Gazette SFRY, International Treaties Nos. 5/1977, Official Gazette, International Treaties No. 12/1993.

\section{CASE LAW}

1. County Court Split, decision no. Gžnš-193/2012 of 11 December 2013.

2. County Court Varaždin, decision no. Gž 1219/2006-02 of 15 May 2006.

3. County Court Varaždin, decision no. Gž 1519/15-3 of 13 January 2016.

4. County Court Varaždin, decision no. Gž-3190/15-2 of 28 September 2016.

5. County court Vukovar, decision no. Gž 1710/2003 of 12 November 2003.

6. County Court Zagreb, decision no. Gžn-1945/10-2 of 8 March 2011.

7. High Commercial Court, decision no. Pž-1010/93 of 18 May 1993.

8. High Commercial Court, decision no. Pž-335/92 of 24 March 1992.

9. Municipal Court Zagreb, decision no. Pn 1088/09 of 23 December 2010.

10. Supreme Court, decision no. Gzz 28/92 of 5 May 1993.

11. Supreme Court, decision no. II Rev 19/1992-2 of 13 December 1994.

12. Supreme Court, decision no. II Rev 22/1992-2 of 28 April 1992.

13. Supreme Court, decision no. Rev 1000/2009-2 of 28 April 2010.

14. Supreme Court, decision no. Rev 1166/04-2 of 14 June 2006.

15. Supreme Court, decision no. Rev 1513/1990-2 of 13 November 1990.

16. Supreme Court, decision no. Rev 218/2008-02 of 13 May 2009.

17. Supreme Court, decision no. Rev 2395/10-2 of 28 December 2012.

18. Supreme Court, decision no. Rev 2480/10-2 of 14 January 2014. 
19. Supreme Court, decision no. Rev 417/93 of 22 December 1993.

20. Supreme Court, decision no. Rev 452/2009-2 of 20 March 2012.

21. Supreme Court, decision no. Rev 744/11-3 of 13 September 2016.

22. Supreme Court, decision no. Rev 878/2008-2 of 18 February 2010.

23. Supreme Court, decision no. Rev x 470/2014-2 of 1 April 2015.

24. Supreme Court, decision no. Rev-x 135/08-2 of 17 June 2009.

25. Supreme Court, decision no. Rev-x 237/13-2 of 28 December 2013.

26. Supreme Court, decision no. Rev-x 280/11-2 of 11 December 2013.

27. Supreme Court, decision no. Rev-x 496/15-2 of 28 July.

28. Supreme Court, decision no. Rev-x 802/13-2 of 26 March 2014.

\section{WEB SITES}

1. Essén, E. W., Explanatory Report of the Convention on the law applicable to traffic accidents, 1970, p. 28. URL= https://assets.hcch.net/upload/expl19e.pdf. Accessed 23 February 2019.

2. Hague conference, Hage Convention of 1971 Status Table. URL= https://www.hcch.net/en/instruments/conventions/status-table/?cid=81. Accessed 19 February 2019.

3. Database of the case law https://sudskapraksa.csp.vsrh.hr/search. Accessed 13 February 2019.

4. Papettas J. on request by the European Parliament's Committee on Legal Affairs, Directorate General for Internal Policies, Policy Department C: Citizens' Rights and Constitutional Affairs, Legal Affairs, Choice of Law for Cross Border Road Traffic Accidents: Rome II, the Hague Convention and the Motor Insurance Directive, PE 462.492, 2012 p. 20. URL= http://www.europarl.europa.eu/document/ activities/cont/201212/20121219ATT58306/20121219ATT58306EN.pdf. Accessed 13 February 2019.

5. Database of the case law www.iusinfo.hr. Accessed 13 February 2019. 
Tena Hoško*

Dora Zgrabljić Rotar**

\section{PRIMJENA HAŠKE KONVENCIJE O PROMETNIM NEZGODAMA IZ 1971. U HRVATSKOJ}

\section{Sažetak}

U radu se analizira praksa hrvatskih sudova o primjeni Haške konvencije o pravu mjerodavnom za prometne nezgode na cestama iz 1971. U relativno recentnoj sudskoj praksi Vrhovnog suda opće kolizijsko pravilo za izvanugovornu odgovornost za štetu primjenjuje se umjesto Konvencije. Riječ je o presudama iz 2009. i 2013. godine koje ukazuju na to da čak i nakon 40 godina primjene postoji problem pri osnovnom razumijevanju izvora međunarodnog privatnog prava. Ipak, postoji niz odluka u kojima je Haška konvencije iz 1971 primijenjena. U toj praksi često su prisutna slična pravna pitanja. Većina njih se odnosi na primjenu članka 8. Konvencije koji uređuje polje primjene mjerodavnog prava ili na primjenu članka 4. Konvencije koji propisuje iznimku od glavnog pravila iz članka 3. Konvencije kojim se propisuje primjena lex loci delicti commissi. Problematična praksa odnosi se na primjenu iznimke iz članka 4. Konvencije. $\mathrm{S}$ druge strane, odluke u kojima se primjenjuje članak 8. Konvencije ukazuju na to da su hrvatski sudovi prepoznali ideju iza te odredbe kako je objašnjena u Essén izvješću, a to je vrlo široko polje primjene mjerodavnog prava na koje upućuje Konvencije.

Ključne riječi: $\quad$ kolizijska pravila za prometne nezgode, Haška konvencija o prometnim nezgodama iz 1971, lex loci delicti commissi, polje primjene mjerodavnog prava

\section{(c) (1) (9)}

This work is licensed under a Creative Commons

Attribution-NonCommercial 4.0 International License.

* $\quad$ Dr. sc. Tena Hoško, docentica, Pravni fakultet Sveučilišta u Zagrebu, Trg Republike Hrvatske 14, 10000 Zagreb, Republika Hrvatska. Adresa e-pošte: tena.hosko@pravo.hr. ORCID: https://orcid.org/0000-0002-6745-0351.

** Dr. sc. Dora Zgrabljić Rotar, docentica, Pravni fakultet Sveučilišta u Zagrebu, Trg Republike Hrvatske 14, 10000 Zagreb, Republika Hrvatska. Adresa e-pošte: dora.zgrabljic.rotar@pravo.hr. ORCID: https://orcid.org/0000-0002-6558-4532. 